\title{
The effects of fire-related cues on seed germination and viability of Helenium aromaticum (Hook.) H.L. Bailey (Asteraceae)
}

\section{Los efectos de las señales del fuego sobre la germinación y la viabilidad de las semillas de Helenium aromaticum (Hook.) H.L. Bailey (Asteraceae)}

\author{
Susana Gómez-González ${ }^{1}$, Cristian Torres-Díaz ${ }^{1}$ \& ERnesto Gianol21 23,4 \\ 'Laboratorio de Genómica y Biodiversidad (LGB), Departamento de Ciencias Básicas, Facultad de Ciencias, Universidad del \\ Bío-Bío, Chillán, Chile. \\ ²Departamento de Botánica, Universidad de Concepción, Casilla 160-C, Concepción, Chile. \\ ${ }^{3}$ Departamento de Biología, Universidad de La Serena, La Serena, Chile. \\ ${ }^{4}$ Center for Advanced Studies in Ecology and Biodiversity (CASEB), Pontificia Universidad Católica de Chile, Santiago, \\ Chile. \\ sgomez@ubiobio.cl
}

\begin{abstract}
RESUMEN
Se evaluó el efecto de la temperatura y el humo sobre la germinación de Helenium aromaticum; una planta anual abundante en matorrales incendiados. Encontramos que las semillas son resistentes a la alta temperatura $\left(100^{\circ} \mathrm{C}\right)$ y al humo, pero su germinación no es estimulada por estos factores. Otras señales del fuego deben ser evaluadas.
\end{abstract}

Lightning-ignited burns are extremely rare in the matorral of Central Chile $\left(25-37^{\circ} \mathrm{S}\right)$. This has led to the notion that natural fires have not played an important role in plant species evolution in the matorral (Armesto \& Gutiérrez 1978, Muñoz \& Fuentes 1989, Montenegro et al. 2004). This particular feature distinguishes the matorral from other Mediterranean-type ecosystems in which fire has shaped a wide variety of plant functional traits, such as germination stimulated by heat-shock or by the chemicals produced by smoke, ash or charred-wood (Keeley \& Fotheringham 2000).

Anthropogenic fires affect thousands of hectares each year in Central Chile, and the matorral is the most damaged ecosystem (CONAF 2010). Severe fires strongly reduce the soil seedbank because native species seeds generally can not tolerate extreme temperatures $\left(\geq 100^{\circ} \mathrm{C}\right.$; Muñoz \& Fuentes 1989, Gómez-González \& Cavieres 2009). However, low-severity fires increase seed survival and seedling establishment in some matorral species (Segura et al. 1998). These superficial fires occur in open grasslands with low fuel load, where soil reaches non-lethal temperatures for seeds $\left(<40^{\circ} \mathrm{C}\right)$ (Gómez-González \& Cavieres 2009). In such conditions, chemicals in smoke or ash could be more relevant than heat in affecting seed germination. Gómez-González et al. (2008) reported smoke-stimulated germination in some pioneer woody species that are common in open matorral grasslands. Although smoke-stimulated germination in species from naturally fire-free habitats has been interpreted as the result of smoke chemicals acting on general germination regulators (see Pierce et al.1995, Van Staden et al. 2000), a selective role of anthropogenic fires in the evolution of this trait is also plausible.

Helenium aromaticum (Hook.) L.H. Bailey (Asteraceae) is an annual (or biannual) native herb that is widely distributed along the Mediterranean region of Chile (Bierner 1978). Helenium aromaticum is a pioneer plant that colonize disturbed and nitrified matorral sites (Gutiérrez 1993), where coexists with several other annual species (mainly aliens) forming seasonal grasslands that surround patches of woody vegetation. Gómez-González \& Cavieres (2009) reported differential effects of fire severity on the emergence of $H$. aromaticum seedlings from the soil seed bank. They found no emergence of seedlings after applying intense fires on soil samples (around $100^{\circ} \mathrm{C}$ at $2.5 \mathrm{~cm}$ soil depth) but significantly higher seedling emergence when fire was of low-intensity (reaching $35^{\circ} \mathrm{C}$ at $2.5 \mathrm{~cm}$ soil depth). Field observations support these results, since we found monospecific stands ( $90 \%$ cover) of this species in lightly burned patches but low colonization on severely burned patches (Gómez-González, unpublished data). This suggests that $H$. aromaticum seeds are vulnerable to the high temperatures reached during severe fires, but when fire is superficial germination could be stimulated, presumably by smoke. 
To assess this hypothesis we subjected $H$. aromaticum seeds to four treatments: i) heat-shock (using an oven at $100^{\circ} \mathrm{C}$ during $5 \mathrm{~min}$ ), ii) plant-derived smoke (cold smoke applied during10 min; see methodological details in GómezGonzález et al. 2008), iii) combination of heat-shock and smoke, and iv) control. Each treatment was applied to $180 \mathrm{H}$. aromaticum seeds, which were distributed in 6 Petri-dishes (30 seeds in each one). After applying the treatments, Petridishes were placed in a growth chamber under favorable conditions ( $12 \mathrm{~h} \mathrm{light} / 20^{\circ} \mathrm{C} ; 12 \mathrm{~h}$ dark $\left./ 10^{\circ} \mathrm{C}\right)$, watered and checked for seed germination on a daily basis during 36 days. Afterwards, we performed a viability test using tetrazolium on non-germinated seeds (TTC $1 \%$ in phosphate buffer, $\mathrm{pH} 6.5-7.5,24 \mathrm{~h}$ in darkness). We evaluated the effect of treatments (fixed factor) on the final germination percentage (number of germinated seeds after 36 days / 30 seeds) using a generalized linear mixed model (binomial GLMM), where Petri-dishes were considered as a random factor $(\mathrm{R}$ 2.8.0 software, R Development Core Team, 2008).

Heat-shock decreased the final germination percentage of $H$. aromaticum from $80 \%$ to $67.7 \%(z=-2.1 ; \mathrm{P}=0.039$; GLMM), while smoke or the combination of heat and smoke produced no effects (smoke: $\mathrm{z}=-1.3, \mathrm{P}=0.176$; heat + smoke: $\mathrm{z}=-1.4, \mathrm{P}=0.153$; GLMM) (Fig. 1). The tetrazolium test revealed that $100 \%$ of non-germinated seeds were viable after the germination essay ended (all treatments), and thus they were dormant seeds. Therefore, heat-shock treatment reduced germination but did not cause seed mortality. Furthermore, heat and smoke together did not affect seed germination, indicating that $H$. aromaticum seeds are resistant to high temperatures. These results support recent evidences demonstrating that native annual species have certain resistance to fire (see Figueroa et al. 2009, Gómez-González et al. 2011). Gómez-González et al. (2011) found increased richness of native annual species in burned matorral areas and suggested that the strong pressure of anthropogenic fires during the last centuries (Aravena et al. 2003) could have selected favorable traits on native species seeds such as harder seed coats. The evolutionary ecology of seed traits in relation to fire needs to be explored in native matorral species to test this hypothesis.

Our results contrast in some way to the pattern of seedling emergence after low- and high-intensity fires reported by Gómez-González \& Cavieres (2009) for this species. Although high temperature did decrease $H$. aromaticum germination, the viability of $H$. aromaticum seeds was not affected. Furthermore, and contrary to expected, smoke did not stimulate seed germination. This could be due to other fire cues not evaluated in this study. The fire experiment performed by Gómez-González \& Cavieres (2009) consisted in burning litter on soil seedbank samples, and thus, other factors such as ash and charred-wood were also involved. It has been shown that ash alone stimulates seed germination of many mediterranean species (Keeley \& Fotheringham 2000) but its effects can be inhibitory when combined with high temperatures (González-Rabanal \& Casal 1995). Therefore, the effect of these factors on seed germination of $\mathrm{H}$. aromaticum should be addressed to reveal the mechanisms by which this native species increases its emergence and establishment only in burned grasslands of the Chilean matorral.

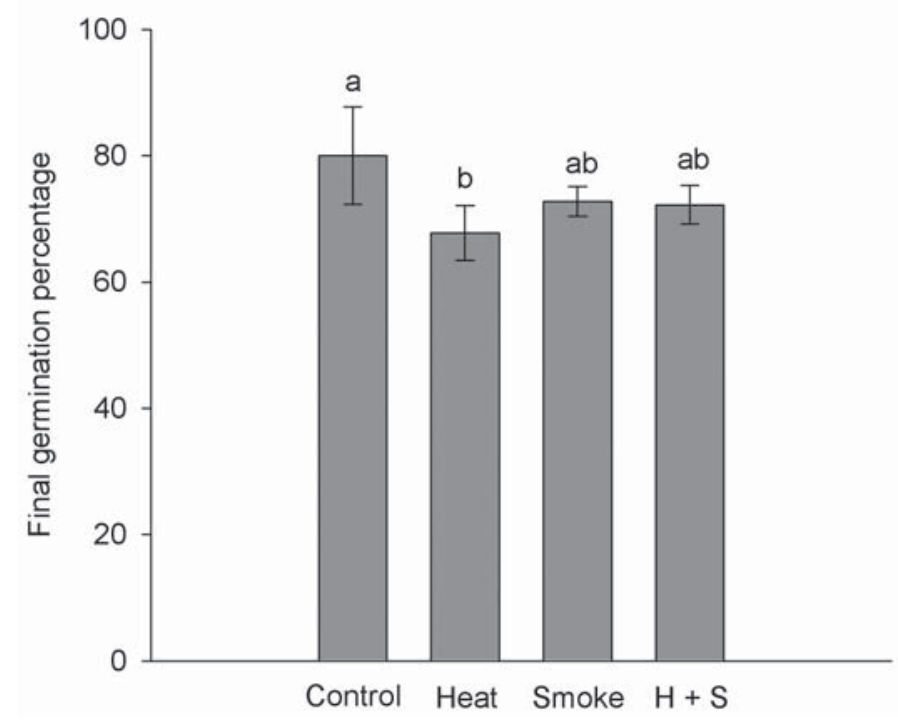

FIGURE 1: Effect of heat, smoke and the combination of both factors $(\mathrm{H}+\mathrm{S})$ on the final germination percentage of $H$. aromaticum. Mean values $\pm 2 \mathrm{SE}$ are shown, $\mathrm{n}=6$. Different letters denote significant differences among treatments $(\mathrm{P}<0.05 ; \mathrm{GLMM})$.

Figura 1: Efecto del calor, el humo y la combinación de ambos factores $(\mathrm{H}+\mathrm{S})$ sobre el porcentaje de germinación final de H. aromaticum. Se muestran los valores medios $\pm 2 \mathrm{EE}, \mathrm{n}=6$. Las letras diferentes denotan diferencias significativas entre tratamientos $(\mathrm{P}<0,05 ; \mathrm{GLMM})$. 


\section{ACKNOWLEDGMENTS}

We thank anonymous reviewers for their comments. Funded by Fondo Nacional de Desarrollo Científico y Tecnológico (Postdoctoral Grant FONDECYT-3090018). Project sponsored by Universidad de Concepción.

\section{REFERENCES}

Aravena, J.C., C. le Quesne, H. Jiménez, A. Lara \& J.J. Armesto. 2003. Fire history in central Chile: Tree-ring evidence and modern records. In: T.T. Veblen, W.L. Baker, G. Montenegro \& T.W. Swetnam (eds.), Fire and Climatic Change in Temperate Ecosystems of the Western Americas, pp. 343-356. Springer, New York, USA.

Armesto, J.J. \& J. Gutiérrez. 1978. El efecto del fuego en la estructura de la vegetación de Chile central. Anales del Museo de Historia Natural (Valparaíso) 11: 43-48.

Bierner, M.W. 1978. The taxonomy of Helenium sect. Cephalophora (Asteraceae). Systematic Botany 3: 277298.

CONAF. 2010. Estadísticas Históricas Incendios Forestales. Corporación Nacional Forestal de Chile, Ministerio de Agricultura. URL:http: \www.conaf.cl.htm Accessed: October 7, 2010.

Figueroa, J.A., L.A. Cavieres, S. Gómez-GonzÁlez, M.A. MolinaMontenegro \& F.M. JAKsic. 2009. Do heat and smoke increase emergence of exotic and native plants in the matorral of central Chile? Acta Oecologica 35: 335-340.

Gómez-GonzÁlez, S. \& L.A. CAVIERes. 2009. Litter burning does not equally affect seedling emergence of native and alien species of the Mediterranean-type Chilean matorral. International Journal of Wildland Fire 18: 213-221.

Gómez-GonzÁlez, S., A. Sierra-Almeida \& L.A. Cavieres. 2008. Does plant-derived smoke affect seed germination in dominant woody species of the Mediterranean matorral of central Chile? Forest Ecology and Management 255: 1510-1515.

Gómez-GonzÁlez, S., C. Torres-Díaz, G. Valencia, P. Torres-Morales, L.A. Cavieres \& J.G. Pausas. 2010. Anthropogenic fires increase alien and native annual species in the Chilean coastal matorral. Diversity and Distributions 17: 58-67.

González-Rabanal F. \& M. Casal. 1995. Effect of high temperatures and ash on germination of ten species from gorse shrubland. Vegetatio 116: 123-131.

GutiérREZ J.R. 1993. The effect of water, nitrogen, and humaninduced desertification on the structure of ephemeral plant communities in the Chilean coastal desert. Revista Chilena de Historia Natural 66: 337-344.

Keeley, J.E. \& C.J. Fotheringham. 2000. Role of fire in regeneration from seed. In: M. Fenner (ed.), Seeds: the Ecology of Regeneration in Plant Communities, pp. 311330. CAB International, Oxon, UK.

Montenegro, G., R. Ginocchio, A. Segura, J.E. Keeley \& M. GómEz. 2004. Fire regimes and vegetation responses in two Mediterranean-climate regions. Revista Chilena de Historia Natural 77: 455-464.

Muñoz, M.R. \& E.R. Fuentes. 1989. Does fire induce shrub germination in the Chilean matorral? Oikos 56: 177-181.

Pierce, S.M., K. Esler \& R.M. Cowling. 1995. Smoke-induced germination of succulents from fire-prone and fire-free habitats in South Africa. Oecologia 102: 520-522.

R Development Core Team. 2008. R: A language and environment for statistical computing. R Foundation for Statistical Computing, Vienna. URL:http://www.r-project.org.htm Accessed: Jun 21, 2010.

Segura, A.M., M. Holmgren, J.J. Anabalón \& E.R. Fuentes. 1998. The significance of fire intensity in creating local patchiness in the Chilean matorral. Plant Ecology 139: 259-264.

Staden, J. van, N.A.C. Brown, A.K. Jäger \& T.A. Johnson. 2000. Smoke as a germination cue. Plant Species Biology 15: 167-178.

Recibido: 08.11.10

Aceptado: 02.12.10 